\title{
Calvin AND MISSION
}

\section{Author:}

Jacobus (Kobus) P.

Labuschagne $^{1}$

\section{Affiliation: \\ ${ }^{1}$ Department of Church \\ History and Church \\ Polity, University of \\ Pretoria, South Africa}

Correspondence to:

Jacobus (Kobus) P.

Labuschagne

\section{e-mail:}

kobus.labuschagne@

up.ac.za

\section{Postal address:}

Department of Church

History and Church Polity,

Faculty of Theology,

University of Pretoria,

Lynnwood Road, 0083

Hatfield, South Africa

\section{Keywords:}

Calvin; mission; Reformed

Church; protestantism;

evangelism

\section{Dates:}

Received: 25 May 2009

Accepted: 06 July 2009

Published: 12 Nov. 2009

How to cite this article

Labuschagne, J.P., 2009,

'Calvin and mission',

HTS Teologiese/Theological

Studies 65(1), Art. \#310, 8

pages. DOI: $10.4102 /$ hts

v65i1.310

\section{This article is available}

at:

http://www.hts.org.za

Note:

This article is a reworked version of a 'working draft', published in

Theology and the Church in South Africa, Journal of the Africa Institute for Missiology 1(1), 2009, 18-41.

(C) 2009. The Authors. Licensee: OpenJournals Publishing. This work is licensed under the Creative Commons Attribution License.

\section{ABSTRACT}

It has often been stated or implied that John Calvin and the Reformers in general were indifferent to or even against mission. The aim of this study is to point out that this understanding is not a true version of the facts. A thorough examination of the theology and actions of John Calvin, evaluated against the background of his times and world, reveals that he was firmly committed to spreading the Gospel of Jesus Christ, the Lord. Also the theological insights of Calvin and the Reformers not only provided the crucial theological basis to support the future massive missionary expansion of Protestant churches, but necessitate for all times Church mission as a sure consequence of their theology. Calvin's theology can indeed be described as an 'essentially missionary theology'. In the heart of Calvin's theological thinking clearly features the doctrine of justification - because medieval man's concern for salvation needed to be answered.

\section{INTRODUCTION: THE QUESTION OF A MISSIONARY CONCERN}

It has often been stated or implied that Calvin and the Reformers in general were indifferent to or even against mission, or that they regarded the missionary task of the church as being limited to the apostles. Gustav Warneck (1834-1910), the father of missiology as a theological discipline, was one of the first Protestant scholars convinced that Calvin and the Reformers had no missionary concern (Bosch 2004:244). A.M. Hunter even went so far as to state in his book on Calvin's teaching: 'Certainly he [Calvin] displayed no trace of missionary enthusiasm' (Van Neste 2009:1). Others held an entirely different view and noted 'an intensified zeal for evangelism' in Calvin (Van Neste 2009:1).

The aim of this study was to question the view that Calvin was indifferent to or even against mission and to point out that such a view does not represent a true version of the facts. This view is naturally also not true of the Reformation as such. Sometimes, even scholars tend to come to conclusions too easily. On these occasions they tend to criticise without necessarily taking into account the whole or full corpus of a theologian's thoughts, arguments and situation. It should be borne in mind that the massive missionary expansion of Calvinistic or Reformed Churches during the 19th century was to a great extent a development based on Calvin's theology. This immediately points to Calvin's theology as being a theology with a missionary inclination. We therefore need to gain a proper insight into John Calvin's theology and what he is really teaching us within the context of his world and situation. At the end of this study we will be able to agree with Ray van Neste who emphasises that '... a close examination of Calvin's historical context, his writings, and his actions would prove John Calvin to be a man truly committed to the spread of the gospel' (Van Neste 2009:1).

\section{THE ESSENTIALLY MISSIONARY THEOLOGY OF JOHN CALVIN (10 JULY 1509-27 MAY 1564)}

A characteristic feature of the 16th century Reformation was that the Reformers never embarked on religious activities and ventures without establishing a definite background of profound theological thinking beforehand. In this regard Frank A. James III stresses the following:

Calvin ... did not want to send uneducated missionaries back to the dangers of Catholic France. He believed that a good missionary had to be a good theologian first. And so he inspired and educated them. He trained them theologically, tested their preaching ability, and carefully scrutinized their moral character.

(Coleman 2009:2)

Errol Hulse elaborates on the moral conduct that was necessarily part of being a good minister and a good theologian in Calvin's book:

There was an exacting code listing offences that were not to be tolerated in a minister. Offences in money, dishonesty or sexual misconduct meant instant dismissal.

(Hulse 2009:3)

Hulse also relates Calvin's own profound theological abilities at an early age (shortly after his arrival in Geneva at the age of 27):

Not long after this the Roman Catholic priests of the nearby city of Lausanne were challenged to a public debate by the Reformers. Of 337 priests only 174 arrived and only 4 had the ability to defend their doctrine. Farel and Viret, a foremost Swiss Reformer of those times, were spokesmen for the Bible. They took Calvin with them as an observer as he had no experience of these debates. The debate went on for several days. One priest in defence of transubstantiation started to quote from the Early Church Fathers. Farel and Viret were unable to handle this and looked to Calvin for help. Standing up the latter proceeded to quote from memory passages from the Early Church Fathers, giving the exact source in each case. It was an amazing display of learning and had an electrifying effect on the assembly. The opposition was completely confounded. One priest was converted immediately. As a result of this astonishing performance not only did Lausanne turn Protestant but 200 priests renounced the Roman Catholic Church.

(Hulse 2009:1-2) 
For the kind of approach that the Reformers had, the entire practical enterprise of reforming and rebuilding the Christian church had to be built on a sound theological foundation. It can be argued that the worldwide expansion and lasting successes of the Reformation were directly related to the impact which the theological thinking of the Reformers had on people's minds. That means that before we can even begin to try and understand the Reformers' and in particular John Calvin's thinking on mission, we need to search for and understand the basic theological thinking that necessarily underlies any approach to and involvement in important theological and church matters.

Joel R. Beeke regarded it as a time constraint, which temporarily delayed massive overseas foreign missionary work because Calvin and the Reformers first had to ascertain the truth of the Gospel in the infant Reformation church, thus establishing a necessary and sound theological foundation upon which church mission could be built (cf. Coleman 2009:2).

According to David J. Bosch there could be little doubt that the Reformers gave us an 'essentially missionary theology' (Bosch 2004:245). This, of course, includes John Calvin, and the intention of this study is to focus mainly on Calvin. However, we also cannot entirely isolate Calvin's thinking from the rest of the Reformation, because his theology formed part of the Reformation debate of the 16th century. In addition, John Calvin was a prominent leader in the Reformation movement as a whole. To appreciate the unique contribution of John Calvin, this study discloses Calvin's theology with reference to David J. Bosch, who identified five crucial and basic theological insights into Reformation theology which 'help us to discern the contours of a "Protestant theology of mission"', namely: (1) The doctrine of justification; (2) the perspective of the essential sinfulness of man; (3) the subjective dimension of salvation; (4) the priesthood of all believers; and (5) the centrality of the Scriptures (Bosch 2004:241-252). In reflecting and elaborating on these five theological contours, the following should be pointed out in order to demonstrate the profound theological basis which Calvin's theology provides for the mission of the Church (cf. Bosch 2004:241-252).

\section{The doctrine of justification}

The Reformation's understanding of the doctrine of justification is already an understanding conducive to mission.

It is Calvin's 'conviction' (Institutes, Book III, Chapter XI) that the 'doctrine of justification' is 'the principal ground on which religion must be supported'. This means that from the 'foundation' of the doctrine of justification man's 'position ... before God', his 'salvation' and 'piety towards God' need to be understood and explained (Calvin 1964:37). The predicament of man's position is that man is a sinner with no righteousness before God. 'To be justified in the sight of God', salvation is man's greatest need, and Calvin explains:

A man is said to be justified in the sight of God when in the judgement of God he is deemed righteous, and is accepted on account of his righteousness; for as iniquity is abominable to God, so neither can the sinner find grace in his sight, so far as he is and so long as he is regarded as a sinner. Hence, wherever sin is, there also are the wrath and vengeance of God. He, on the other hand, is justified who is regarded not as a sinner, but as righteous, and as such stands acquitted at the judgement-seat of God, where all sinners are condemned. ... On the contrary, a man will be justified by faith when, excluded from the righteousness of works, he by faith lays hold of the righteousness of Christ, and clothed in it appears in the sight of God not as a sinner, but as righteous. Thus we simply interpret justification, as the acceptance with which God receives us into his favour as if we were righteous; and we say that this justification consists in the forgiveness of sins and the imputation of the righteousness of Christ....

(Calvin 1964:37-38)
It is Christ that died, yea rather, that is risen again, who is even at the right hand of God, who also maketh intercession for us. (Rm Viii. 33-34)...To justify, therefore, is nothing else than to acquit from the charge of guilt, as if innocence were proved. Hence, when God justifes us through the intercession of Christ, he does not acquit us on a proof of our innocence, but by imputation of righteousness, so that though not righteous in ourselves, we are deemed righteous in Christ.

(Calvin 1964:39)

It is clear to Calvin that Christ is in fact the only ground for man's justification, and faith is an empty vessel for the purpose of receiving the decisive content: the God-man Jesus Christ, man's Saviour (Niesel 1980:137). But faith's encounter with Jesus Christ does not leave man unchanged. In Christ a new life is resurrected. Niesel explains Calvin's understanding as follows:

But this Christ whom we receive in faith through the action of the Holy Spirit does not leave us undisturbed in our old manner of life which was hostile to God, but attracts us into His own dying and rising again.

(Niesel 1980:130, 131)

Undoubtedly, the doctrine of justification was to 16th century Protestantism the doctrine by which everything in church and theology stood or fell - 'articulus stantis et cadentis ecclesiae' (Bosch 2004:241). The reason for this was that at the heart of Calvin's theology, as well as at the heart of Reformation theology ( $c f$. the first question of the Heidelberg Catechism), figured man's concern for salvation that needed answers. The doctrine of justification had to respond to precisely that.

Understandably Calvin also refers to the doctrine of justification as the doctrine of salvation. For instance, in his Last Will and Testament Calvin dictated (as recorded by Theodore Beza):

thanks to God, that taking mercy on me, ... he not only delivered me out of the deep darkness... that he might bring me into the light of his Gospel, and make me a partaker in the doctrine of salvation, of which I was most unworthy...

(Beza 1964:207)

For many, in the light of the message of the Gospel of Jesus Christ, the theology of the Middle Ages dismally failed to provide the answers to man's critical questions on personal salvation. To follow the teachings of the Medieval church without questioning any of them did not satisfy everyone. In Reformation theology everything is in some way or another inextricably linked to the most important doctrine of justification, which ultimately focuses on every individual's salvation. The moment we emphasise every man's salvation, this doctrine becomes something about which all people across the entire world and certainly every individual should really know. And then, logically and consequently, this doctrine (together with all related doctrines) necessarily becomes foundational to the mission of the church. For Calvin and the Reformation, the faith that follows from the justification in Jesus Christ is always a faith that has to be shared with others, and always a caring faith concerned with the wellbeing and salvation of all people.

However, the point of departure for the Reformers in the doctrine of justification is not what people can and ought to do for their salvation, but what God has already done for their salvation in Jesus Christ. What God has done can be received by faith alone - sola fides. God has done all this in his love and his sovereignty, by grace alone - sola gratia. Man can in no way whatsoever contribute to his own salvation. At the basis of this doctrine is the conviction of the Reformers that there is a great distance (difference) between God and man, in fact all of God's creation. This means that there is an ongoing dialectical tension between God and man - definitely also in Calvin's theology. Again: all of mankind is therefore in need of salvation - and that in itself is already enough reason for mission, so that every individual may hear the Gospel's message of salvation.

The emphasis by the Reformers on the idea that all initiative concerning man's salvation is in the hands of God might explain 
why in more orthodox circles there is a tendency to give up the dialectical tension between God and man, i.e., the 'creative tension' (Bosch), and to put all the emphasis on God's saving work, with man in the process withdrawing from the scene and the church losing its missionary vision (cf. Bosch 2004:250).

However, to argue that the 16th century Reformers had no missionary vision is misguided and built on a misunderstanding of the basic substance of Reformation theology and ministry. Against this misunderstanding would argue the whole weight of Calvin's pneumatology, in addition to the already mentioned argument of the individual's concern for salvation, which figures in the centre of the doctrine of justification, and which necessitates the spreading of the Gospel and a missionary vision. Calvin stressed two aspects in his pneumatology: (i) The work of the Holy Spirit in the renewal of the individual human spirituality; and (ii) the activity of the Spirit in the renewal of the world. He elaborates on these two dimensions of his pneumatology in Book III, chapter XX,42, by referring to the individual that has to be purified from all corruptions and to the whole world that needs to be brought to the voluntary obedience of all minds and hearts:

his Spirit corrects all the depraved lusts of the flesh when he brings our thoughts into obedience to his authority. This petition, therefore, is duly presented only by those who begin with themselves; in other words, who pray that they may be purified from all the corruptions which disturb the tranquillity and impair the purity of God's kingdom. Then as the word of God is like his royal sceptre, we are here enjoined to pray that he will subdue all minds and hearts to voluntary obedience. This is done when by the secret inspiration of his Spirit he displays the efficacy of his word... God, therefore, sets up his kingdom, by humbling the whole world, though in different ways...

(Calvin 1964:189)

When referring to the two dimensions in Calvin's pneumatology, the renewal of the individual and the transforming of the world, Bosch says:

For Calvin, the Christ who was exalted to God's right hand was pre-eminently the active Christ. In a sense, Calvin subscribed to an eschatology in the process of being fulfilled. He used the term regnum Christi (the reign of Christ) in this respect, viewing the church as intermediary between the exalted Christ and the secular order. Such a theological point of departure could not but give rise to the idea of mission as 'extending the reign of Christ', both by the spiritual renewal of individuals and by transforming the face of the earth through filling it with 'the knowledge of the Lord'.... In most of the early seventeenth century Second Reformation theologians - G Voetius, J Heurnius, W Teellinck, and others - the two dimensions were held together in a creative tension.

(Bosch 2004:256)

Calvin's views on predestination (as an explanation as to why some people are drawn to faith and others not) have often been 'targeted as unevangelistic and destructive to missionary zeal' (Van Neste 2009:2). However, this view has in fact inspired Calvin to encourage Christians to become involved in spreading the Gospel. In his treatise, Concerning the Eternal Predestination of God, Calvin says:

Since we do not know who belongs to the number of the predestined and who does not, it befits us so to feel as to wish that all be saved. So it will come about that, whoever we come across, we shall study to make him a sharer of peace...even severe rebuke will be administered like medicine, lest they should perish or cause others to perish. But it will be for God to make it effective in those whom he foreknew and predestined.

(Van Neste 2009:2)

When comparing the view of John Calvin and Martin Luther on mission, it is noticeable that Luther linked foreign mission to brotherly love. According to Walter Holsten, Luther believed that if a Christian were to find himself among non-Christian people he would be under the obligation to preach and teach the gospel to the erring pagans or non-Christians because of the duty of brotherly love, even if no human being had called him to do this.

(Bosch 2004:245)

\section{The perspective of the essential sinfulness of man}

Calvin explains man's innate sinfulness (Institutes, Book II, Chapter I) as follows:

Therefore, since through man's fault a curse has extended above and below, over all the regions of the world, there is nothing unreasonable in its extending to all his offspring...This is the hereditary corruption to which early Christian writers gave the name of Original Sin, meaning by the term the depravation of a nature formerly good and pure...it was clearly proved from Scripture that the sin of the first man passed to all his posterity... The orthodox, therefore, and more especially Augustine, laboured to show that we are not corrupted by acquired wickedness, but bring an innate corruption from the very womb. It was the greatest impudence to deny this.

(Calvin 1964:214)

In addition, Calvin says (Institutes, Book I, Chapter VI \& VII, Book II, Chapter IX):

Since the human mind, through its weakness, was altogether unable to come to God if not aided and upheld by his sacred word, it necessarily followed that all mankind ...inasmuch as they sought God without the Word, were labouring under vanity and error.

(Calvin 1964:67)

...our conviction of the truth of Scripture must be derived from a higher source than human conjectures, judgements, or reasons; namely, the secret testimony of the Spirit.

(Calvin 1964:71)

By the Gospel, I understand the clear manifestation of the mystery of Christ.

(Calvin 1964:364)

The Reformation saw man primarily from the perspective of the essential sinfulness of humanity, the Fall, and man's inability to save himself. The Reformation broke with Thomas Aquinas's hermeneutics of a two-fold approach of nature and grace - in a combination of Greek philosophy (Aristotle) and Biblical theology. The Reformation therefore rejected Aquinas's optimistic view of the abilities of human reason and made people conscious of their lost condition as sinners.

A preoccupation with human depravity may also, for some, lead to non-involvement in mission on the part of man, because humans are, in any event, unable to change the reality in which they find themselves.

Calvin's threefold understanding of history opposed any notion of human non-involvement. He discerned three stages in the progression of the church: The first stage was during the time of the apostles, when the Gospel was offered to the whole inhabited world. The second stage was a time of constantly being under threat of the antichrist, a time that also occasioned the life of Calvin. The third stage would mark the great expansion of the church. What could have been expected was that when, for instance, the later Puritans accepted Calvin's understanding of history, they saw themselves as being at the beginning of the third period and they were convinced of their own role in the great expansion. But then, being more radical, they had their own ideas and agendas (cf. Bosch 2004:260, 313).

It is important that the mission of the church in Calvin's theocratic mind needs to be comprehended - in the period between the ascension and the parousia of Christ - as 'an inaugurated eschatology' (Bosch 2004:515). This means the church is involved in the world and in the future. In Calvin's understanding of history and the future (eschatology), salvation 
history is not opposed to profane history, nor grace to nature. Subsequently, what follows is a positive attitude of Christian involvement towards what may be achieved in this world (Bosch 2004:516). With this view, Christ's order of life and society is something that progresses throughout the world, and the church and Christians are instrumental in the furtherance of faith and the values of Christ's reign within this unjust world (cf. Bosch 2004:516).

Calvin does not interpret God's initiative and saving act in Christ in any way that would exclude human responsibility and involvement. Human responsibility and involvement are indeed part of the mission of the church in this world.

\section{The subjective dimension of salvation}

Part of Reformation theology is the emphasis on the subjective dimension of salvation. With this, the worth of the Christian individual is being brought to the fore and evidently promoted. Already during the late Middle Ages individuals became aware of themselves as people in their own right, as opposed to the group and the community. Calvin highlights the subjective dimension of salvation - and the human existential tension experienced - in the encounter with God in Jesus Christ, in faith (see Calvin's reference to Christ in John 3:16; 5:24 and 6:35):

He who believes in him is said to have passed from death unto life ... He, I say, was our witness, that all by whom he is received in faith will be regarded by our heavenly Father as sons.

(Calvin 1964:245)

Relation, interaction and tension are herewith experienced in the individual's existential encounter in faith, which ultimately leads to the transformation of existence into a new life of being children of God. The sometimes harsh and rigid portrayal of what Calvin's doctrine of election supposedly said, comes into question when Calvin himself explains this doctrine in relation to the human existential experience of faith, as well as in relation to Jesus Christ (Institutes, Book III, Chapter XXIV, 5 \& 6), as an election in Christ and in faith:

Hence, those whom God has adopted as sons, he is said to have elected, not in themselves, but in Christ Jesus (Eph. I. 4); ...Christ, then, is the mirror in which we ought, and in which, without deception, we may contemplate our election. For since it is into his body that the Father has decreed to ingraft those whom from eternity he wished to be his... if we are in communion with Christ, we have proof sufficiently clear and strong that we are written in the Book of Life. ...We are said to be clothed with him, to be one with him, that we may live, because he himself lives. The doctrine is often repeated, "God so loved the world, that he gave his only begotten Son, that whosoever believeth in him should not perish, but have everlasting life".

(Calvin 1964:244-245)

Through the challenge of faith in Reformation thinking and theology, the question about salvation became an existential and personal question of the individual, and a personal responsibility that the individual had to respond to, much more than in the Middle Ages. The challenge of faith is naturally then also part of the missionary situation and the personal challenge in that situation. Rightly Bosch adds to this:

This emphasis would never again disappear; in a thousand different forms believers would insist on the personal and subjective experience of a new birth by the Holy Spirit, as well as on the responsibility of the individual over [and] against the group.

(Bosch 2004:242)

In opposition to Rome, the Reformation preached that God alone, through grace and in Christ, brought salvation to man lost in $\sin$. This did not prevent man from personally and existentially experiencing the gift of faith in his or her life, and necessitated the act of faith, for love of God and all other human beings.

For Calvin, the act of faith is also to be understood as being part of man's sanctification. Niesel emphasises that for Calvin '...justification and sanctification, are never dissociated from each other' (Niesel 1980:137). For Calvin, justification and sanctification form a living unity in Christ, and if we attempt to separate justification from the act of faith in sanctification, we are in fact seeking to break up the unity of the one Christ (Niesel 1980:137, 138). Through sanctification, in the act of faith, the subjective dimension of salvation becomes clearer.

In the Institutes of Calvin the act of faith, as consequence of the gift of faith, clearly stands in relation to the kingdom of God and the reign of God in this world. It is important, when thinking in terms of mission, to note how Calvin explains the kingdom of God and the reign of God in terms of all minds and hearts and also the whole world and increasing numbers in the Third Book, Chapter XX (referring to prayer):

...I now briefly repeat that God reigns....Thus this kingdom consists of two parts: the first is, when God by the agency of his Spirit corrects all the depraved lusts of the flesh ... and the second, when he brings all our thoughts into obedience to his authority. This petition, therefore, is duly presented only by those who begin with themselves; in other words, who pray that they may be purified from all the corruptions which disturb the tranquillity and impair the purity of God's kingdom. Then as the word of God is like his royal sceptre, we are here enjoined to pray that he would subdue all minds and hearts to voluntary obedience. ... God, therefore, sets up his kingdom, by humbling the world, though in different ways, taming the wantonness of some, and breaking the ungovernable pride of others. We should desire... that God may gather churches to himself from all quarters of the world, may extend and increase their numbers, enrich them with his gifts....

(Calvin 1964:189)

\section{The priesthood of all believers}

Emphasising the personal involvement and responsibility of the believer inevitably leads to the concept of the 'priesthood of all believers' (Bosch 2004:242). In Reformation thinking every Christian has a calling and a responsibility to serve God, to be actively involved in God's kingdom in this world. The Reformation breaks with the concept of ordinary believers as not really good enough to serve in the church's ministry in this world. Calvin teaches (Third Book, Chapter X) that every individual Christian, in whatever profession or trade he or she might stand, has a calling and a duty to serve God:

Every man's mode of life, therefore, is a kind of station assigned to him by the Lord... So necessary is this distinction, that all our actions are thereby estimated in his sight, and often in a very different way from that in which human reason or philosophy would estimate them.... it is enough to know that in everything the call of the Lord is the foundation and beginning of right action.

(Calvin 1964:34, 35)

Every individual is called upon to serve Christ in the ministry of his church in this world. With this kind of theological basis the Christian individual is by implication already committed to the missionary task of the church, in whatever occupation and situation the individual might find himself or herself.

\section{The centrality of the Scriptures and the Word as final authority}

In his Institutes (Book IV, Chapter VIII) Calvin stresses that the church is bound by Scripture and obeys Christ as the only teacher of the church, and the Holy Spirit guides in all truth:

The Church (is) astricted to the written Word of God. Christ (is) the only teacher of the Church. From his lips ministers must derive whatever they teach for the salvation of others .....Nothing can be lawfully taught in the Church, that is not contained in the writings of the Prophets and the Apostles, as dictated by the Spirit of Christ.

(Calvin 1964:389)

And because from ignorance they were unable to comprehend the things which they had heard and learned from the lips of their 
Master, the Spirit of truth is promised to guide them unto all truth (John xiv. 26; xvi. 13). The restriction should be carefully attended to. The office which he assigns to the Holy Spirit is to bring to remembrance what his own lips had previously taught.

(Calvin 1964:394)

When referring to Paul in the Epistle to the Colossians, Calvin emphasises (Institutes, Book IV, Chapter X):

...The constitutions which they call ecclesiastical, and by which the Pope, with his adherents, burdens the Church, we hold to be pernicious and impious. ...

(Calvin 1964:419)

In the beginning of the second chapter, he says that all the treasures of wisdom and knowledge are hidden in Christ, and from this he concludes that believers should beware of being led away from the flock of Christ by vain philosophy, according to the constitutions of men (Col. ii. 10).

The centrality of the Scriptures was an important feature in Reformation theology, and this brought an end to Rome's ruling that in all matters of faith the popes and councils of the church had the final say (cf. Lohse 1985:12-22). The centrality of the Scriptures led to a change in the liturgical centre of many churches; the altar was replaced by the pulpit in the central position. It should, however, be emphasised that the Reformers never taught biblical inerrancy, because the focus was actually on something greater than the Scriptures: God's Word, the Word that became man, Jesus Christ, our Lord and God. This means that the Bible is the Word of God in its relation to Jesus Christ, and through the testimony of the Holy Spirit. Verbal inspiration was something that came later, during the post-Reformation.

In his Commentary on Hebrews, when Calvin explains Chapter 1:1-3 (God has spoken to us through his Son), we find an example of his teaching that God's revelation is a revelation in Jesus Christ;

..God is revealed to us in no other way than in Christ.

(Calvin 1963:8)

In maintaining the divinity of Christ, Calvin refers to the author of Hebrews as:

...attributing to Christ what belongs to God alone, and at the same time distinguishing two separate persons in the Father and the Son. Hence we infer that the Son is one God with the Father..

(Calvin 1963:9)

Thus it means that for the Reformation the mission of the church could only be understood on the basis of the Scriptures, and from there, more precisely, on the basis of the Word of God, the Word that became a human being, the Word as final authority.

In conclusion, we now need to realise and emphasise that any examination or estimate of the Reformers' and especially John Calvin's vision of the missionary task of the church has to be understood on the basis of a thorough theological insight: A basic theological insight which encompassed, in the first place, the doctrine of justification and, in relation to this doctrine, the essential sinfulness of man; the human subjective dimension of salvation; the priesthood of all believers; and ultimately, the final authority of the Word of God.

\section{FINDING SOME BALANCE IN EVALUATING CALVIN'S MISSIONARY PARADIGM}

When we consider the theological contours for the mission of the church, as stated above, we can rightly argue that subsequent generations had indeed in Calvin, and the Reformation as a whole, a firm theological basis on which to build. This holds true for the post-Reformation period, especially for the period of rapid missionary expansion in the 19th century, as well as for today.

However, if the Reformation's understanding of mission is measured in a quantifiable sense against the great Protestant missionary expansions of the 19th century, contemporary criticism may presume that the Reformation is lacking in understanding mission. However, this argument can easily be turned around with a detrimental effect on the 19th century's understanding of mission, when the focus shifts from quantity (numbers) to the quality of the theological argument. This is when the anthropological baggage of 19th century missionary thinking - originating from the influences of Humanism, Pietism, and Enlightenment - is judged theologically against the Reformers' point of departure in the sovereignty of God in Jesus Christ, in the doctrine of justification. However, different times and situations cannot be compared and judged that easily, as that would amount to an oversimplification.

It is only fair to consider that the Reformers, in their situation, had their principal task as that of reforming the faith of the church. There was hardly time or much opportunity to embark on foreign mission in far-off countries. They also had to cope with an enormous struggle for survival against the power onslaught of Rome. Since the time of emperor Constantine (c. 274-337), the idea of a Christian state and the interdependence and cooperation between church and state were taken for granted. Because of this predisposition, the Reformers could hardly imagine a missionary outreach into foreign countries in which there were no Lutheran or Reformed government ( $c f$. Bosch 2004:240, 245, 246)

Depending on one's definition of mission, mission could also mean preaching the Gospel with new insight, on the basis of the Scriptures alone, and giving comfort to people seeking light in faith in Jesus Christ alone, as Lord and as Saviour, and not in human abilities and in the rules of Rome's popes and councils. In this sense John Calvin made an enormous contribution towards spreading the Gospel of Jesus Christ to many countries.

Calvin contributed in a worthy way to make Geneva a safe haven for great numbers of fugitives who fled from the fierce religious persecution elsewhere in Europe, especially from France ( $c f$. Hughes 1973:43, 44). Calvin had a natural missionary spirit and a true ecumenical vision which distinguished him in later times. For many fugitives, Calvin changed Geneva in a positive way, i.e., from a place of refuge to a school of opportunity. He gave refugees the best possible theological training and sent them across Europe to countries such as Scotland, England, Italy and France, well-equipped and motivated to take on the responsibility for spreading the Gospel of Jesus Christ to people in need and ignorance and darkness, as it were, to 'teach others the truth that set them free' (Hughes 1973:45). The Scottish Reformer, John Knox, who himself once found a safe haven and theological training in Geneva, said that John Calvin's Geneva was 'the most perfect school of Christ which has been seen on earth since the days of the apostles' (Hughes 1973:44). Philip E Hughes adds: 'Geneva became a dynamic centre or nucleus from which the vital missionary energy it generated radiated out into the world beyond' (Hughes 1973:45).

\section{Calvin's commentaries}

Amazing insights of Calvin's missionary vision are there to be discovered, by making a study of Calvin's vast contribution of Bible commentaries. A few examples can be pointed out:

- With unambiguous clarity Calvin expresses enthusiasm for the spreading of the Gospel in his Dedication to Edward VI, King of England, in his Commentary on Isaiah:

But when, in the brightness of his Gospel, Christ, the Sun of Righteousness, arose, all that had been so eloquently described by the revelations of the prophet was far exceeded by the event. Within a short time the knowledge of the true God was spread almost throughout the whole world. Pure religion, which formerly lay despised in Judea, as in a dark corner, was circulated through all nations and provinces, and began to be honoured in such a manner, that innumerable tongues, in harmony of faith, called on God.

(Calvin 1948c:xxi, xxii) 
- Contrary to the assumption that Calvin and the Reformers restricted the Lord's missionary command to the original apostles, Calvin, in referring specifically to Matthew 28:19 and 14 - and now no longer with the qualification of 'almost throughout the whole world', but with a definite 'all nations' and 'in every part of the world', as future goal - says (in his Commentary on a Harmony of Evangelists, Matthew, Mark, and Luke [Third Volume]):

Teach all nations. Here Christ, by removing the distinction, makes the Gentiles equal to the Jews, and admits both indiscriminately to a participation in the covenant ...but now, the wall of partition having been broken down, (Eph.h ii.14) the Lord commands the ministers of the gospel to go to a distance, in order to spread the doctrine of salvation in every part of the world... Thus was fulfilled that prediction of Isaiah, (xlix.6) and others of similar nature, that Christ was given for a light of the Gentiles, that he might be the salvation of God to the end of the earth.

(Calvin 1949a:384)

We also need to consider what Calvin wrote on verse 14 (which gives this commission time until the last coming of Christ) so that there could be no misunderstanding as to the fact that the commission would not be completed within the lifespan of the original apostles:

And the gospel of the kingdom will be preached throughout the whole world.... As to the objection brought by some, that to this day not even the slightest report concerning Christ has reached the Antipodes and other very distant nations, this difficulty may be speedily resolved; for Christ does not absolutely refer to every portion of the world, and does not fix a particular time, but only affirms the gospel... would be spread to the farthest bounds of the world before the day of his last coming.

(Calvin 1949a:128, 129)

- In his Commentary upon the Acts of the Apostles (Volume I) Calvin refers to the kingdom of Christ, which was to be erected everywhere (Acts 1:8) - and which, in the mind of Calvin, could never have been envisaged as the task of one generation:

Christ testifieth that they must gather thereunto all Samaria; which, although they were nigh in situation, yet were they far distant in mind and heart. He showeth that all other regions far distant, and also profane, must be united unto the holy people, that they may be all partakers of one and the same grace. It is evident (John iv.9) how greatly the Jews did detest the Samaritans. Christ commanded that (the wall of separation being broken down) they be both made one body (Eph. ii.14) that his kingdom may be erected everywhere.

(Calvin 1949b:48)

- In his Commentary on the Gospel according to John (Volume I) Calvin refers to the love of God for the whole of the human race and to God wishing no human being to perish (without exception) - which could only be understood in terms of an ongoing mission of the church across the whole world:

As the whole matter of our salvation must not be sought anywhere else than in Christ, so we must see whence Christ came to us, and why he was offered to be our Saviour. Both points are distinctly stated to us: namely, that faith in Christ brings life to all, and that Christ brought life, because the Heavenly Father loves the human race, and wishes that they should not perish....

... Hence it follows that, until Christ bestow his aid in rescuing the lost, all are destined to eternal destruction.

...It is a remarkable commendation of faith, that it frees us from everlasting destruction ...And he has employed the universal term whosoever, both to invite all indiscriminately to partake of life, and to cut off every excuse from unbelievers. Such is also the import of the term World ...he shows himself to be reconciled to the whole world, when he invites all men without exception to the faith of Christ ...

(Calvin 1949c:123, 124, 125)

- In his Commentary on Romans (Chapter 10:9-19), Calvin makes an important connection between three realities: (i) God's mission; (ii) the preaching of the church (as 'instrument of his power' - God's power); and (iii) the salvation of 'the whole world' - 'any nation' (Calvin 1947:396-404). This is of course important for the vision of the ongoing mission of the church in this world, and for the motivation that missionary work has to be aimed at the whole world. Calvin says:

Where then there is a calling on God, there is faith; and where faith is, the seed of the word has preceded; where there is preaching there is the calling of God... It will hence at last appear that the Gentiles are not to be excluded from the kingdom of God, for God has admitted them into a participation of his salvation.

(Calvin 1947:397)

Since the minds of men are imbued, by preaching, with the knowledge of God, which leads them to call on God, it remained a question whether the truth of God had been proclaimed to the Gentiles; for that Paul had suddenly betaken himself to the Gentiles, there was by that novelty no small offence given. He then asks, whether God had ever before directed his voice to the Gentiles, and performed the office of a teacher towards the whole world. But in order that he might show that the school, into which God collects scholars to himself from any part, is open in common to all, he brings forward a Prophet's testimony from Ps. xix.4..

...God has already from the beginning manifested his divinity to the Gentiles, though not by the preaching of men, ... yet the whole workmanship of heaven and earth did speak and make known its author by its preaching.

...for by the word going forth the Prophet reminds us, that the doctrine, of which the heavens are the preachers, is not included within the narrow limits of one land, but is proclaimed to the utmost regions of the world.

...Paul had argued, that the Gentiles were not to be excluded from the knowledge of God, since he had from the beginning manifested himself to them....

(Calvin 1947:402-404)

- In his Commentary on the Epistles of Paul the Apostle to the Corinthians Calvin writes (with reference to 2 Corinthians $2: 12$, 13) about the necessary concern for the welfare of the whole church of Christ, as 'our duty', and about opportunities to preach the Gospel that should always be made use of. These matters are indeed closely linked to the missionary calling of the church. Calvin explains:

- just as at this day it is our duty, indeed, to promote the welfare of the whole Church, and to be concerned for the entire body of it....

(Calvin 1948a:156)

...so where an opportunity presents itself of edifying, let us consider that by the hand of God a door is opened to us for introducing Christ there, and let us not withhold compliance with so kind of indication from God.

(Calvin 1948a:155)

- In his Commentary on 1 Timothy, in explaining Chapter 2:4, which, without a doubt, points to mission as an ongoing challenge of the church, Calvin says that the Gospel should be proclaimed to all people without exception:

... for the Apostle simply means, that there is no people and no rank in the world that is excluded from salvation; because God wishes that the gospel should be proclaimed to all without exception.

(Calvin 1948b:54, 55)

His missionary vision is already evident in Old Testament commentaries, for instance in his Commentary on the Book of the Prophet Isaiah (Chapter 45:23), where Calvin explains that the worship of God shall be spread among all nations. Calvin says of the prophet:

...he means that all the Gentiles shall be suppliants to God... Yet hence also it follows, that his worship shall be spread among all nations; for we cannot truly 'bend the knee' before God till he hath been made known to us. To an unknown God, indeed, men may render some kind of worship; but it is false and unprofitable. But here he speaks of a true profession, which proceeds from a knowledge of God deeply seated in our hearts; for, where there is 
no faith, there can be no worship of God, and faith is not directed to a thing unknown or uncertain.

- In his Commentary on Ezekiel (Chapter 18:23), Calvin teaches that God does not wish the death of one sinner, but wishes all people to be converted. The missionary challenge is, indeed, the conversion of all people. Note also the words, all ages. Referring to the Prophet, Calvin says:

He confirms the same sentiment in other words, that God desires nothing more earnestly than that those who were perishing and rushing to destruction should return into the way of safety. And for this reason not only is the Gospel spread abroad in the world, but God wishes to bear witness through all ages how inclined he is to pity...

God is said not to wish the death of a sinner. How so? Since he wishes all to be converted. Now we must see how God wishes all to be converted; for repentance is surely his peculiar gift: as it is his office to create men, so it is his province to renew them, and to restore his image within them.

(Calvin 1948e:246, 248)

Nevertheless, the very important point still remains that Calvin, and the Reformers, made us the beneficiaries of their profound theology, and in this way they guide and teach us to discern the contours of a Reformed or Protestant theological understanding of church mission. The consequence of this heritage was clearly visible during the 'age of mission', the 19th century, when large numbers of missionaries of Calvinistic origin were sent across the world to far-off foreign countries. Keith Coleman concludes: 'By the end of the 19th century one quarter of all Protestant missionaries in the world were Presbyterian' (Coleman 2009:5). B.B. Warfield adds the following: 'Calvinistic churches are today behind none in their zeal for a success in missionary work' (Coleman 2009:5)

\section{THE REGISTER OF THE COMPANY OF PASTORS IN GENEVA}

In the Registers of Geneva, the numbers of ministers trained in Geneva and sent out from there are far from complete and are restricted, in the main, to a few years between 1555 and 1562 . Because of the unbridled hostilities against the Reformation, the utmost secrecy had to be observed in many cases when sending out evangelical preachers. In practice this meant that many names and destinations were actually deleted from the Registers, and some names were changed in order to make identification impossible. The names in the Registers probably represent only a fraction of the real numbers of trained ministers who left Geneva to preach the Gospel in other countries. The Register of the Company of Pastors in Geneva lists the names of 88 ministers who were sent out to various places, for the period 1555 to 1562 . Robert M. Kingdon proves the incompleteness of the Register by taking 1561 as an example. Indications are that 1561 was a peak year for this kind of missionary activity. However, the Register records that only twelve men were sent out, whereas evidence from other sources totals no fewer than 142 names (Hughes 1973:46)

Despite dreadful persecutions, the growth of the Protestant church in France between 1555 and 1562 was spectacular. The many preachers who were sent from Calvin's Geneva to France contributed much to this impressive growth. In this regard Hulse (2009:3) reports as follows:

All Calvin's students had to be fully proficient in Latin, Hebrew and Greek, in order to be thoroughly proficient in line by line exegesis of the Scriptures.

They were required to be trained in Church History and Systematic Theology... Only when Calvin judged a man to possess the necessary fibre and stamina would he be sent into France to preach and plant churches. Each church began by a group gathering in a home, and then out of that a fully disciplined church would be constituted. Such was termed 'a dressed church'.
In 1555 there was only one 'dressed church'. Seven years later, in 1562, there were 2150 such churches! This represents growth of extraordinary proportions. Eventually there were over two million Protestant church members out of a French population of twenty million. The multiplication came in spite of fierce persecution. For instance in 1572, 70,000 Protestants lost their lives... There were 29 national synods from about 1562 to 1685 when persecution forced most of the believers to leave France.

(Hulse 2009:3)

\section{THE MISSION TO BRAZIL}

There are people with the conviction that only missions to indigenous people in far-off countries where there are no Western influences, could count as real missionary work. A venture that would probably capture their imagination took place when two ministers were dispatched from Calvin's Geneva across the Atlantic Ocean to Brazil. The Register for 1556 merely states that on Tuesday, 25 August 1556, August Pierre Richier and Guillaume Charretier were sent off to minister in the islands recently conquered by France, off the coast of Brazil. It also states that they 'were subsequently commended to the care of the Lord and sent off with a letter', i.e. from the church in Geneva (Hughes 1973:47). The broader picture of what happened is to be collected from other sources. Of particular importance in this regard is the detailed account and extensive observations gathered in Jean de Léry's journal (under the title Histoire d'un voyage fait en la terre de Brésil) published in Geneva in 1578. After his return from Brazil, Léry was ordained and became a noted minister in the Reformed Church (cf. Beaver 1973:55-73).

Villegagnon, Vice-Admiral of Brittany, was the man at first inspired and determined to undertake a colonial expedition to Brazil. He was then also appointed governor of the expedition to Brazil, to colonise an area, the first in a region that would be known as France Antartique. Well-known Huguenots joined the expedition. However, Villegagnon received authorisation for the expedition only after he had won the support of the Grand Admiral of France, Gaspard de Coligny. He gave the admiral the impression of a positive approach towards the Protestants. By then, Coligny was already known for his interest in and protection of the Huguenots, and at a later stage he announced that he was a member of the Reformed Church. Coligny found favour with the royal court and through his intervention Henry II authorised the expedition. The small fleet of three ships reached Guanabara (Rio de Janeiro) on 10 November 1555. Villegagnon chose a small island that was apparently easy to defend.

Following unrest amongst his own people, Villegagnon turned to the Huguenots for help. When his ships sailed for France in February 1556, they carried his requests to Coligny and the church of Geneva. When the question of mission was put before the church of Geneva, they responded favourably. Léry wrote:

Upon receiving these letters and hearing the news, the church of Geneva at once gave thanks to God for the extension of the reign of Jesus Christ in a country so distant and likewise so foreign and among a nation entirely without knowledge of the true God.

(Beaver 1973:61)

It subsequently followed that Pierre Richier (aged 50) and Guillaume Charretier (aged 30) were sent to Brazil. Calvin had knowledge of the mission to Brazil, as is evident from correspondence on the matter (Beaver 1973:62). The instructions were to establish a colony in South America, free from persecution, where they could develop their own culture and at the same time instruct the heathen Indians in the Gospel of Jesus Christ.

Though the ministers were in the beginning not too sure of success in their mission to the Indians (the Tupinambas), and they perceived the language barrier as an enormous obstacle, they were later more motivated and hopeful. They decided to advance their work by stages and began to master the language 
of the Indians. Richier wrote to Calvin: 'Since where the Most High has given us the task, we expect this Edom to become a future possession for Christ' (Beaver 1973:64).

Ultimately, and regrettably, the expedition failed and was aborted. Villegagnon was not a successful governor. He betrayed Coligny's trust in him, and later turned against the Huguenots and persecuted them. Léry wrote:

It is my opinion that if Villegagnon had not turned against the Reformed religion, and if we had been able to remain in that country for a longer time, we would have drawn and won over some of them to Christ.

(Beaver 1973:65)

The expedition, nonetheless, presents us with a brilliant example of the missionary vision and far-reaching insight of John Calvin and his colleagues in Geneva.

It is furthermore interesting and noteworthy that three years prior to the Brazilian expedition, a letter was sent from the Company of Pastors of Geneva to 'the believers of certain islands in France', giving them advice and sending them a minister (who carried this letter with him). No names of persons or places were mentioned. The letter was signed: 'Charles d'Espeville in the name both of himself and of his brethren'. Charles d'Espeville was an assumed name and we know now that Calvin sometimes used that assumed name (Hughes 1973:48)

\section{FINAL REMARKS: AN ESSENTIALLY MISSIONARY THEOLOGY}

There are present-day historians who still argue that Calvin and his fellow Reformers did not have a missionary concern. There can be no doubt that their arguments lack the required substantiation.

In his Commentary on Micah (Mic. 2:1-4) Calvin describes the missionary work of the church as an ongoing process: 'The Kingdom of Christ was only begun in the world, when God commanded the gospel to be everywhere proclaimed, and .... at this day its course is not yet complete' (Hughes 1973:56-57).

Surely some form of mission is required for the proclamation of the Gospel everywhere and, by implication, to all people without exception, as stated by Calvin. The theology of Calvin is, without a doubt, an essentially missionary theology.

When a theology is not conducive to spreading the Gospel of Jesus Christ the Lord, it means that it is not an essentially missionary theology. For Calvin that would mean that there is something dreadfully wrong with the faith of such a theology. According to Calvin, the faith that follows from the justification in Jesus Christ is always a faith that has to be shared with others, and is a caring faith, concerned with the well-being of all people and the salvation of all people. This is in fact the message of Calvin and the Reformation, if the Reformation's doctrine of justification is to be understood correctly. This surely is something to remember for all times: There must be something dreadfully wrong with a person's faith - and something extremely misguided in his or her theology - when in the practice of Christian life the missionary spirit is not there. Faith is there to be lived, for the individual's own sake and for the sake of others.

The miraculous and rapid spreading of the Gospel of Jesus Christ as a result of the faith of the Reformation is embedded in the history of that period, for all to discover and to learn from.

Calvin's missionary concerns are particularly evident in these words, and worthy to be remembered (Book III, chapter XX, 42): 'We should desire...that God may gather churches to himself from all quarters of the world, may extend and increase their numbers, enrich them with his gifts...' (Calvin 1964:189).

\section{REFERENCES}

Beaver, R.P., 1973, 'The Genevan Mission to Brazil', in J.H. Bratt (ed.), The heritage of John Calvin, pp. 55-73, W.M.B. Eerdmans, Grand Rapids.

Beza, T., 1964, 'Life of Calvin', in H.J. Hillerbrand (ed.), The Reformation in its own words, pp. 207-208, SCM Press, London.

Bosch, J.B., 2004, Transforming mission: Paradigm shifts in theology of mission, Orbis Books, Maryknoll.

Bratt, J.H., 1973, The heritage of John Calvin, W.M.B. Eerdmans, Grand Rapids.

Calvin, J., 1947, Commentaries on the epistle of Paul the Apostle to the Romans, transl. J. Owen (ed.), W.M.B. Eerdmans, Grand Rapids.

Calvin, J., 1948a, Commentary on the epistles of Paul the Apostle to the Corinthians, vol. II, transl. W. Pringle, W.M.B. Eerdmans, Grand Rapids.

Calvin, J., 1948b, Commentaries on the epistles to Timothy, Titus, and Philemon, transl W. Pringle, W.M.B. Eerdmans, Grand Rapids.

Calvin, J., 1948c, Commentary on the Book of the Prophet Isaiah, vol. 1, transl. W. Pringle, W.M.B. Eerdmans, Grand Rapids.

Calvin, J., 1948d, Commentary on the Book of the Prophet Isaiah, vol. 3, transl. W. Pringle, W.M.B. Eerdmans, Grand Rapids.

Calvin, J., 1948e, Commentary on the first twenty chapters of the Book of the Prophet Ezekiel, transl. T. Myers, W.M.B. Eerdmans, Grand Rapids.

Calvin, J., 1949a, Commentary on a harmony of the evangelists, Matthew, Mark, E Luke, vol. 3, transl. W. Pringle, W.M.B. Eerdmans, Grand Rapids.

Calvin, J., 1949b, Commentary upon the Acts of the Apostles, vol. 1, transl. H. Beveridge (Latin), transl. C. Fetherstone (English), W.M.B. Eerdmans, Grand Rapids.

Calvin, J., 1949c, Commentary on the Gospel according to John, vol. 1, transl. W. Pringle, W.M.B. Eerdmans, Grand Rapids.

Calvin, J. ,1963, Calvin's commentaries: Hebrews and I E II Peter, transl. W. Johnston, ed. by D.W. Torrance \& T.F. Torrance, W.M.B. Eerdmans, Grand Rapids.

Calvin, J., 1964, Institutes of the Christian religion, WM.B. Eerdmans, Grand Rapids.

Coleman, K., 2009, Calvin and missions, 1-5, viewed n.d., from http://www.wrs.edu/Materials_for_Web_Site/Journals/ 16-1_Feb-2009/Coleman--Calvin_Missions.pdf

Hillerbrand, H.J., 1964, The Reformation in its own words, SCM Press, London.

Hughes, P.E., 1973, 'John Calvin: Director of missions', in J.H. Bratt (ed.), The heritage of John Calvin, W.M.B. Eerdmans, Grand Rapids.

Hulse, E., 2009, John Calvin and his missionary enterprise, 1-4 viewed n.d., from http://reformed-theology.org/html/ issue04/calvin.html.

Lohse, B., 1985, A short history of Christian doctrine: From the first century to the present, transl. F.E. Stoeffler, Fortress Press, Philadelphia.

Niesel, W., 1980, The theology of Calvin, transl. H. Knight, Baker Book House, Grand Rapids.

Van Neste, R., 2009, John Calvin on evangelism and mission, 1-6, viewed n.d., from http://www.founders.org/journal/fj33/ article2.html. 